\title{
Actores y ritual cívico durante el porfiriato: la celebración del día de la independencia en Sinaloa, México, 1888-1910*
}

\section{Rafael Santos Cenobio}

Profesor de la Universidad Autónoma de Sinaloa (México). Correo electrónico: rafaelsantos921@gmail. com. El autor es doctor en Ciencias Sociales de la Universidad de Guadalajara (México). Entre sus publicaciones recientes tenemos: "Los maestros rurales en Sinaloa: pedagogos, promotores de la salud y activistas político-sociales", Ra Ximhai Vol. 13 No. 2 (2017). Entre sus temas de interés están: Historia política, Vida cotidiana, Movimientos sociales e Historia de la educación.

Recibido: 01 de diciembre de 2017

Aprobado: 8 de junio de 2018

Modificado: 14 de junio de 2018

Artículo de investigación científica

DOI: http://dx.doi.org/10.15648/hc.34.2019.2

Este artículo forma parte del proyecto: "Espectáculos, diversiones y carnavales en Sinaloa, 18881913" financiado por el Consejo Nacional de Ciencia y Tecnología (México).

Esta publicación está bajo una licencia Creative Commons Reconocimiento-NoComercial 4.0 
Actores y ritual cívico durante el porfiriato: la celebración del día de la independencia en Sinaloa, México, 1888-1910

\title{
Resumen
}

Este artículo estudia el proceso histórico de la celebración del día de la independencia en Sinaloa, México, a través de dos generaciones que se encargaron de la escenificación del esplendor del poder; aunque también funcionaron como bastiones de la disidencia política que dio nacimiento al movimiento revolucionario sinaloense. El ritual cívico tuvo dos fases, una que va de 1888 a 1903, caracterizado por el auge del fervor patriótico; y el segundo se extiende de 1904 a 1910, marcado por el Centenario de la Independencia.

Palabras clave: Generación, ritual cívico, sociabilidad e independencia.

Actors and civic ritual during the Porfiriato: the celebration of Independence Day in Sinaloa, Mexico, 1888-1910

\begin{abstract}
This article studies the historical process of the celebration of Independence Day in Sinaloa, Mexico, through two generations that were in charge of the staging of the splendor of power; although they also functioned as bastions of the political dissidence that gave birth to the Sinalo an revolutionary movement. The civic ritual had two phases, one that goes from 1888 to 1903 , characterized by the rise of patriotic fervor; and the second extends from 1904 to 1910, marked by the Centennial of Independence.
\end{abstract}

Keywords: Generation, civic ritual, sociability and independence.

Atores e rito cívico durante o porfiriato: a comemoração do dia da independência em Sinaloa, no México, 1888-1910

\section{Resumo}

Esse artigo estuda o processo histórico da comemoração do dia da independência em Sinaloa, No México, através de duas geraçóes que se encarregaram da encenada de esplendor do poder; embora também funcionassem como bastióes da dissidência política que deu origem ao movimento revolucionário de Sinaloa. O rito cívico teve duas etapas, a primeira que vai de 1888 até 1903, caracterizado pelo Auge do fervor patriótico: e o segundo que se estende de 1904 até 1910, marcado pelo centenário da independência.

Palavras-chave: Geração, rito cívico, sociabilidade, e independência. 


\section{Acteurs et rituels civiques pendant le Porfiriato: la célébration du Jour de IIndépendance à Sinaloa, Mexique, 1888-1910}

\section{Résumé}

Cet article étudie le processus historique de la célébration du Jour de l'Indépendance à Sinaloa, au Mexique, à travers deux générations qui étaient chargées de la mise en scène de la splendeur du pouvoir; bien qu’ils aient aussi fonctionné comme des bastions de la dissidence politique qui a donné naissance au mouvement révolutionnaire Sinaloan. Le rituel civique a eu deux phases, une qui va de 1888 à 1903, caractérisée par l'élévation de la ferveur patriotique; et le second s'étend de 1904 à 1910, marqué par le centenaire de l'indépendance.

Mots clés: Génération, rituel civique, sociabilité et indépendance.

\section{INTRODUCCIÓN}

Este artículo analiza el proceso histórico de las festividades cívicas como la celebración del día de la independencia ${ }^{1}$ a través de la lente de dos generaciones, una que experimentó el ascenso a la gubernatura de Francisco Cañedo, y fue la encargada de escenificar el poder por medio de rituales cívicos; la otra le tocó vivir el relajamiento del fervor patriótico y el esplendor del Centenario de la Independencia.

1 La conmemoración del día de la independencia de México, se ha celebrado el 15 y 16 de septiembre en relación a los acontecimientos que se sucedieron en 1810, año en el que el cura Miguel Hidalgo y Costilla llamó a la rebelión una madrugada de finales del verano desde la puerta de la iglesia parroquial de Dolores, pueblo cercano a Celaya. La conspiración provinciana de salón que culminó once años después con la independencia tenía como figura central al padre Hidalgo y otros jóvenes militares como Ignacio Allende y Juan Aldama. El plan para separar la Colonia del dominio español se había programado para diciembre de 1810, pero al ser descubierto por las autoridades reales, obligó a Hidalgo y sus acompañantes a levantarse en armas prematuramente del 15 al 16 de septiembre. El ejército insurgente numeroso pero mal armado fue derrotado en enero y para julio de 1811, Hidalgo y sus generales fueron capturados y ejecutados; aun así la insurgencia pervivió en el centro y sur del país bajo la guerra de guerrillas. Muerto Hidalgo, la lucha fue seguida por el párroco José María Morelos quien también fue ejecutado por los realistas a fines de 1815, y los rescoldos de la insurgencia pervivieron como guerra de guerrillas, bandidaje político y los levantamientos locales. Finalmente, en 1821 Agustín de Iturbide fraguó una alianza política y militar con algunos elementos de la vieja dirigencia insurgente; y como derivación realizó un tratado de negociación con el último Virrey declarando la independencia de México. Eric Van Young, La otra Rebelión. La lucha por la independencia de México, 1810-1821. (México: Fondo de Cultura Económica, 2006), 89-92. 
La festividad y el ritual cívico en México y América Latina es un tema muy estudiado por historiadores, sociólogos y antropólogos, sobre todo en 1910, estimulado por los bicentenarios de las independencias -y el centenario de la Revolución mexicana- en los países latinoamericanos. Los enfoques y análisis varían, se estudió también el arte, los museos, la arquitectura, el urbanismo, los monumentos, las plazas y las calles ${ }^{2}$; la función política de las conmemoraciones, mitos, héroes, discurso, nacionalismo, valores patrióticos, memoria histórica, memoria colectiva, discurso, identidad nacional, modernidad, turismo, historia anticuaria, crítica y de bronce ${ }^{3}$; los rituales y su simbolismo, indigenismo, educación y civismo e iconografía ${ }^{4}$; etapas y procesos de las celebraciones a lo largo de la historia ${ }^{5}$; asimismo, se han producido trabajos sobre rituales religiosos como Semana Santa y santos patronos ${ }^{6}$.

2 Laura Malosetti Costa, "Arte e historia en los festejos del centenario de la revolución de mayo en Buenos Aires", Historia Mexicana Vol. LX, No. 1 (2010): 439-470; Sebastián Vargas Álvarez, "Monumento Estela de Luz: disputa en torno a los usos públicos de la historia en el México del Bi/ Centenario", Tempo e Argumento No. 19 (2016): 130-161; Verónica Zárate Toscano, "Los hitos de la memoria o los monumentos en el centenario de la independencia de México. Ópera imaginaria en una obertura", Historia Mexicana Vol. LX, No. 1 (2010): 85-135.

3 Nora Rabotnikof, "El Bicentenario en México: la historia desde la política”, Revista de sociología, No. 24 (2010): 221-222; Alberto Escovar Wilson-White, "Bogotá en tiempos de la celebración del primer centenario de la independencia", Historia Mexicana Vol. LX, No. 1 (2010): 525-559; Luis Ricardo Dávila, "Centenario e inventario de los problemas venezolanos", Historia Mexicana Vol. LX, No. 1 (2010): 243-249; Ana M. Fernández Poncela, "Conmemoraciones, lugares de la memoria y turismo: Querétaro", Alegatos No. 73 (2009): 532-554; Sandra Patricia Rodríguez Ávila, "Construcción de la memoria oficial en el Centenario de la Independencia: el Compendio de Historia de Colombia de Henao y Arrubla”, Folio No. 32 (2010): 23-42; Oscar Alzaga Sánchez, "Del bicentenario de la Independencia, el centenario de la Revolución y la historia”, Alegatos No. 75 (2010): 629-638; Alejandra Marta Mailhe, "Discursos e independencia en América Latina: reflexiones críticas", Revista de Filosofía y Teoría Política No. 41 (2010): 157-175; John Jaime Correa Ramírez, "El discurso del civismo en Pereira o la 'sacralidad' de lo público durante el siglo XX", Historielo No. 2 (2009): 7-31; Liliana M. Brezzo, "Reparar la nación' discursos históricos y responsabilidades nacionalistas en Paraguay", Historia Mexicana Vol. LX, No. 1(2010): 197-242; Guillermo Bustos Lozano, "Del primer centenario de la independencia ecuatoriana: los sentidos divergentes de la memoria nacional", Historia Mexicana Vol. LX, No. 1 (2010): 473-524; Antonio Annino y Francois-Xavier Guerra (Coods.), Inventando la nación. Iberoamérica. Siglo XIX (México: Fondo de Cultura Económica, 2003).

Antonio Sáez-Arance, "Entre la autocomplacencia y la crisis: discursos de chilenidad en el Primer Centenario", Historia Mexicana Vol. LX, No. 1 (2010): 369-396; Gabriel Cid, "Ritos para una nueva legitimidad: ceremoniales constitucionales y republicanismo en Chile (1812-1833)", Historia Crítica No. 47 (2012): 17-43; Daniela Marques del Castillo, "La fiesta del Cinco de Mayo en San Luis Potosí, 1862-1867" (tesis de licenciatura en Historia, Universidad Autónoma de San Luis Potosí, 2009); Alejandra López Gallegos y Aquiles Amparán, "Símbolos, lenguaje y espectáculos en la democracia: el escepticismo político de Murray Edelman", Espiral No. 50 (2011): 101-139; Diego P. Roldán, "Imágenes, juegos, rituales y espacios. Las interacciones socioculturales entre la elite y sectores populares durante las entreguerras. La incultura en Rosario (Argentina)”, Historia No. 28 (2009): 683-714.

5 Sandra Patricia Rodríguez Ávila, "Conmemoraciones del cuarto y quinto centenario del ' 12 de octubre de 1492': debates sobre la identidad americana”, Revista de Estudios Sociales No. 38 (2009): 64-75.

6 Nelson E. Pereyra Chávez, "Historia, Memoria, identidad y performance en una fiesta: la Semana Santa de Ayacucho", Dialogía Vol. 4 (2009): 222-263. 
El trabajo que aquí se presenta se limita a dos ejes de análisis. Los actores y promotores de la organización de las festividades cívicas, aunados al cambio como elemento central en el estudio del día de la independencia de 1888 a 1910. Metodológicamente para observar a los actores se recurrió al concepto de generación, que implicó definir dos fases, una que dominó de 1888 a 1903, integrada por una élite intelectual -acuerpada en el Colegio Civil Rosales, eran catedráticos, estudiantes, periodistas, escritores, poetas y políticos- que se interesó por escenificar y legitimar el poder a través de rituales y oraciones cívicas, desfiles, tertulias, círculos literarios, fiestas populares y relaciones de sociabilidad. Una característica principal de esta generación es que les tocó vivir el ascenso al poder de Francisco Cañedo como gobernador de Sinaloa y de Porfirio Díaz como presidente de México. La segunda generación -nació en la época de estabilidad política y prosperidad económica- se limita al periodo de 1904 a 1910, lapso en el que se relajó el fervor patriótico, aunque luego vino la ostentación del Centenario de la Independencia. Muchos de estos jóvenes se sumaron a la oposición política del régimen porfirista y después se lanzaron a la Revolución mexicana.

En cuanto a la celebración del día de la independencia, se analiza en dos fases. La primera se circunscribe de 1888 a 1903, caracterizada por el auge del fervor patriótico escenificado a través de desfiles de carros alegóricos, caminatas, procesiones y discursos cívicos, tertulias, bailes populares, lecturas del acta de independencia, creación de monumentos en honor a los héroes de la independencia. La segunda etapa va de 1904 a 1910, considerada como el periodo del relajamiento del fervor nacionalista, lo cual se debió a que el país se encontraba pacificado y el régimen envejecía, y los jóvenes se inclinaron más por fundar escuelas, realizar rituales y festividades escolares, al mismo tiempo aparecieron otros espectáculos y diversiones públicas como el cinematógrafo, acrobacia, circos y carnavales modernos que atrajeron la atención de la población. Hacia el Centenario de la Independencia en 1910, el ritual cívico adquirió nuevos bríos, pero ya fue al final del porfiriato.

La investigación sobre la conmemoración del día de la independencia durante el porfiriato se centra en las dos ciudades más importantes de Sina- 
loa: la primera es Culiacán, la capital del estado, ubicada en el centro de la entidad; y la segunda se refiere a Mazatlán, localizada en el sur del Estado, con un intenso dinamismo social, económico y político. En ese sentido el trabajo se inscribe dentro de la historia regional, para eso fue necesario entender la región como una construcción social e histórica ${ }^{7}$-es una realidad cambiante, producto de la dinámica socioeconómica y a la vez integra espacios sociales y lugares vividos con una especificidad que le otorga una estructura propia- ubicada en un espacio con sus características propias y, que sus límites/fronteras no tienen que ver con división política o administrativa de los estados nacionales, más bien está sujeta en el tiempo a la capacidad de territorialización de las elites regionales y los grupos sociales dominantes, así como a los efectos provocados por los movimientos de población y las lógicas particulares nacidas de procesos económicos internos ${ }^{8}$.

\section{Celebración del día de la Patria en MéXico}

El régimen porfirista para pacificar y estabilizar el país recurrió al consenso popular, borró los frentes entre liberales y conservadores, se reconcilió con la Iglesia, permitió a los caudillos gozar de sus feudos a cambio de lealtad y centralizó el poder en torno a su persona9 ${ }^{9}$. Este sistema resultó tan eficaz que la reelección de Díaz no causó ningún problema y para legitimar el poder se optó por la ficción democrática ${ }^{10}$. Producto de la prosperidad económica en algunas ciudades de México proliferaron organizaciones corporativas de obreros ${ }^{11}$ que se fundieron en el mutualismo, los gremios, cofradías y sindicatos católicos. Su objetivo fue ayuda mutua, educación,

$7 \quad$ Ronny J. Viales Hurtado, "La región como construcción social, espacial, política, histórica y subjetiva. Hacia un modelo conceptual/relacional de historia regional en América Latina”, Geopolítica (s) Revista de estudios sobre espacio y poder Vol. 1, No. 1 (2010): 160.

8 Arturo Taracena Arriola, "Propuesta de definición histórica para región", Estudios de historia moderna y contemporánea de México No. 35 (2008): 188-189; Eric Van Young, "Haciendo historia regional. Consideraciones metodológicas y teóricas”, Anuario No. 2 (1987): 262; María Silvia Leoni, "Historia y región: la historia regional de cara al siglo XXI", Folia Histórica del nordeste No. 24 (2015): 172.

9 Knight Alan, La Revolución mexicana. Del porfiriato al nuevo régimen constitucional (México: Fondo de Cultura Económica, 2010), 41-42.

6010 Francois-Xavier Guerra, México: del Antiguo Régimen a la Revolución (México: Fondo de Cultura Económica, 1988), 236 y 211.

11 En el seno de esas organizaciones obreras -Sociedad de Artesanos de Puebla-integradas por abogados, médicos y funcionarios fue donde germinó la oposición a Díaz. 
reuniones, organización de veladas y de fiestas con el fin de salvaguardar o recrear los vínculos personales en una sociedad amenazada por el crecimiento de la industria moderna ${ }^{12}$.

El régimen de Díaz para legitimar el poder recurrió a la teatralidad, seleccionando un pasado colectivo, reserva de imágenes, de símbolos, de modelos de acción, historia idealizada y mitos de héroes ${ }^{13}$. La historia ${ }^{14}$ sirvió para crear una conciencia histórica que buscaba forjar un patriotismo de los ciudadanos, alimentar el orgullo nacional, cultivar el espíritu de sacrificio y esfuerzo por la patria y, generar la conciencia de que la época presente es feliz desenlace de una evolución histórica.

Lo nacional y lo patriótico se representan en las figuras de los caudillos. El proceso de la sacralización del poder de Díaz culminó con la construcción, en 1910, del Hemiciclo a Juárez en la Alameda, que significaba el mito y el símbolo del liberalismo triunfante ${ }^{15}$. La historia y la creación de mitos y héroes fueron utilizadas por el régimen para nutrir el patriotismo y como instrumento de glorificación de Díaz.

Durante el porfiriato, la escenificación del poder era representada en la celebración del día de la independencia, con el fin de buscar los orígenes de la patria en el movimiento insurgente y en la figura de Miguel Hidalgo. La independencia se festejó junto con el movimiento de Reforma, porque era interpretada como la Segunda Independencia. Los fundadores de la

12 Francois-Xavier Guerra, México..., 176.

13 Georges Balandier, El poder en escenas. De la representación del poder al poder de la representación (Barcelona: Ediciones Paidós, 1994), 18-19.

14 La historia practicada en el porfiriato. Historia patria o monumental, se refiere a lo escrito y a la arquitectura pública, los monumentos, la puntura histórica y las estatuas. Un ejemplo, el libro de Justo Sierra, la Evolución política del pueblo mexicano, selecciona héroes nacionales, jefes indígenas que luchan contra Cortes, los de la Reforma y los de la guerra de intervención. Sobre las pinturas están La fundación de México de Joaquín Ramírez (1889) o Moctezuma II visita en Chapultepec los retratos de sus antecedentes (1895) de Daniel del Valle. Historia crítica, su representante Bulnes atacó los mitos de la historia patria, en uno de sus libros, El Verdadero Juárez critica al héroe de la Reforma. Annick Lempériere, "Los dos centenarios de la independencia mexicana (1910-1921): de la historia patria a la antropología cultural", Historia Mexicana Vol. 45, No. 2 (1995): 327-328; Enrique Florescano, "Patria y nación en la época de Porfirio Díaz", Signos Históricos No. 13 (2005): 169.

15 Lara Campos Pérez, "La república personificada. La fiesta porfiriana del 2 de abril (1900-1911)", Estudios de Historia Moderna y Contemporánea de México No. 51 (2016): 55. 
patria fueron visualizados mediante pinturas, esculturas y monumentos, emisión de medallas, fotografías en los periódicos, artes que en este tiempo ayudaron a configurar la imagen del héroe ${ }^{16}$. Aunado a esto se efectuaron procesiones cívicas, discursos, cantos y loas. Así fue como se construyó una Religión de la Patria ${ }^{17}$.

La celebración de los días festivos significaron declaraciones espectaculares de la cultura dominante, ya que mostraban una expresión de gobernabilidad: "Orden y Progreso, el eslogan e ideal de los positivistas comteanos de la nación que animaba las políticas administrativas e inspiraba los despliegues gubernamentales durante los años del régimen porfirista ${ }^{18}$. Los rituales de la patria ${ }^{19}$ durante el régimen de Díaz tienen diferentes etapas ${ }^{20}$. De 1877 a 1882, surgió la junta patriótica y los festejos cívicos de corte aristocrático, ya que la celebración se reducía a un grupo muy selecto que se reunía en espacios cerrados donde hacía gala de banquetes, brindis y discursos ${ }^{21}$.

16 Enrique Florescano, "Patria y nación en la época de Porfirio Díaz", 155.

17 Guillermo Brenes Tencio, "Héroes y liturgias del poder: la ceremonia de la apoteosis", Revista de Ciencias Sociales No. 106 (2004): 110.

18 William H. Beezley, La identidad nacional mexicana: la memoria, la insinuación y la cultura popular en el siglo XIX (México: El Colegio de la Frontera, El Colegio de San Luis y El Colegio de Michoacán, 2008), 87-88.

19 Los insurgentes se preocuparon por mantener la memoria de los héroes patrios que iniciaron la guerra de independencia en 1810. Ignacio López Rayón, en 1812 creó los primeros festejos patrios: el de los onomásticos de Allende e Hidalgo (31 de julio y 29 de septiembre) y 16 de septiembre. En 1822, la conmemoración nacional del 16 de septiembre fue celebrada por antiguos insurgentes y simpatizantes, lo cual contrastaba con la Consumación, el Plan de Iguala y con la coronación de Iturbide. Al ser derribado el emperador Iturbide, el gobierno republicano trató de borrar la memoria del primer emperador mexicano, y realzó la gesta independentista y sus héroes. Para 1823, se estableció como festejo oficial el 16 de septiembre, Hidalgo fue nombrado Padre de la Patria y, los restos de Morelos se trasladaron a la capital de la República. Después de la guerra de reforma tras el triunfo de la República, las conmemoraciones de la gesta independentista dependieron de los logros del gobierno en turno: el 16 de septiembre se resumió en la inauguración del ferrocarril que conectaba Puebla con la ciudad de México y el primer recorrido fue presidido por el presidente Benito Juárez.

Enrique Rajchenber y Aleida García Aguirre, "Memoria e historia en los cumpleaños de la Patria", Bajo el Volcán Vol. 10, No. 16 (2011): 21-22.

20 Arnaldo Moya Gutiérrez, "Los festejos cívicos septembrinos durante el porfiriato, 1877-1910”, en Modernidad, tradición y alteridad, la ciudad de México en el cambio del siglo (XIX-XX), eds. Claudia Agostini y Elisa Epeckman (México: Instituto de Investigaciones Históricas-UNAM, 2001), 51; Pablo Serrano Álvarez, Porfirio Díaz y el porfiriato. Cronología (1830-1915) (México: Instituto Nacional de Estudios Históricos de la Revolución Mexicana, 2012), 11.

21 Lara Campos Pérez, "La república personificada. La fiesta porfiriana del 2 de abril (1900-1911)”, 56. 
En 1883, en la ciudad de México y otras partes del país irrumpió el espectáculo moderno, en los rituales cívicos participaron masivamente obreros, grupos mutualistas, estudiantes, clubes y autoridades civiles y religiosas; hubo procesiones y paseos cívicos, gallos, bailes y banquetes, sumado a la lectura del acta de independencia emanada de Chilpancingo - no el de Iturbide-en la noche del grito. Para este momento se comenzó a institucionalizar el onomástico de Porfirio Díaz, para no confundirlo con las patrióticas fiestas del 15, se eligió el 18 de septiembre. Pero, para 1885, el natalicio de Díaz -el 15 de septiembre- pasó a formar parte del ritual cívico de la nación. En ese sentido, la imagen de Díaz - como la patria sustantivada - fue equiparada a los próceres de la independencia como Hidalgo, Morelos, Mina, Matamoros, Guerrero e Iturbide ${ }^{22}$. Así fue como surgió la lujosa celebración de la alta sociedad, donde se fundieron las ideas del liberalismo porfirista con la victoria de la independencia, que sirvió para dictar el modelo de comportamiento para el resto de la población ${ }^{23}$.

De 1901 a 1910 se escenificó la preparación y la celebración del Primer Centenario de la Independencia. El ritual del día de la patria realizado en la capital mexicana y en los Estados se organizó con derroches y exóticos arreglos que trataban de venerar y adorar al gran representante de la patria, Díaz. Los provincianos replicaron el ritual con fastuosidad: las calles, las plazas y los edificios públicos fueron adornados pormenorizadamente; hubo desfile de carros alegóricos, procesiones, bailes, oración cívica, lectura del acta de independencia y la comida ofrecida a los asistentes.

\section{Protagonistas de la organización del Ritual cívico: los Ja- COBINOS}

En Sinaloa, la Junta Patriótica fue la comisión encargada de organizar las festividades cívicas del 5 de febrero, día de la promulgación de la Constitución Política; el 2 de abril, Batalla de Tuxtepec, protagonizada por Porfirio Díaz; el 5 de mayo, la Batalla de Puebla; el 22 de diciembre, Batalla de San

22 Arnaldo Moya Gutiérrez, "Los festejos cívicos septembrinos durante el porfiriato, 1877-1910”, 6063.

23 William H. Beezley, La identidad nacional, 103. 
Pedro, encabezada por el general sinaloense Antonio Rosales contra los franceses; y el 15 y 16 de septiembre se conmemoraba el día de la independencia ${ }^{24}$. La junta era nombrada por el gobernador o por el presidente del ayuntamiento, cuyos integrantes conformaban la élite cañedista ${ }^{25}$. Ellos recaudaban recursos por medio de funciones teatrales, corrida de toros, bailes y, colectas entre empleados municipales y estatales, y entre comerciantes e industriales, sociedades y organizaciones obreras.

De 1888 a 1910 miembros de dos generaciones ${ }^{26}$ de la élite intelectual ${ }^{27}$ y política cañedista -integrada por periodistas, poetas, profesores, abogados e ingenieros- dominaron las juntas patrióticas en el distrito de Culiacán. Una generación se entiende como un sujeto colectivo que vive en el mismo tiempo, que comparte las mismas historias de amor y odio, influencia social y política, conflictos generacionales, marcados por los mismos acontecimientos y cambios. Aunado, a las propensiones de obrar, sentir y pensar de cierta manera, así como a una misión o proyecto histórico, lo que da formalmente una conciencia histórica. La combinación entre influencias recibidas e influencias ejercidas explica el concepto de sucesión de generaciones. Es un encadenamiento derivado del cruce entre la transmisión de la experiencia y la apertura de nuevas posibilidades ${ }^{28}$.

24 Cinthia Guadalupe Jorquera Núnéz, "La transformación de la vida cotidiana en Culiacán durante la época del cańedismo (1877-1909)" (tesis de licenciatura en historia, Universidad Autónoma de Sinaloa, 2017), 155.

25 En Sinaloa la era de Francisco Cańedo se inició con el triunfo de la revuelta de Tuxtepec encabezada por el general Díaz en 1877, y terminó con la muerte del general Cañedo en 1909. Esta etapa de la historia nacional corresponde a la denominada el porfiriato, momento que muestra mayor integración de Sinaloa a la sociedad nacional. Sergio Ortega Noriega, Breve historia de Sinaloa (México: El Colegio de México y Fondo de Cultura Económica, 1999), 241.

26 Para profundizar en el tema de las series de las generaciones véase en Julián Marías, El método histórico de las generaciones (Madrid: Revista de Occidente, 1949), 151-185; Luis González, Pueblo en Vilo (Zamora: El Colegio de Michoacán, 1995).

27 El intelectual protagoniza el tiempo histórico en el que vive, explicando su mundo por medio de la inteligencia y convirtiéndose en el intelectual político que influye en la justificación del poder, por parte de la élite que toma decisiones. La definición de intelectual incluye el perfil y posición de estos frente al poder, siendo estas mismas enunciaciones la justificación del propio perfil y carrera. En el porfiriato la élite intelectual se situó en el partido científico, un grupo cercano al control financiero encabezado por José Ives Limantour, atrayendo la inversión y la influencia ideológica europea hacia el país. Los científicos adoptaron como filosofía el positivismo evolucionista de Comte y Spencer, mientras que en lo económico se acercaron a la teoría de Adam Smith. Pedro Ángel Palou, "Intelectuales y poder en México", América Latina Hoy No. 47 (2007): 78-80.

28 Reinhar Koselleck, Los estratos del tiempo: estudios sobre historia (Barcelona: Ediciones Paidós, 2001), 39-40; Juan María Sánchez-Prieto, "Historia y generaciones: la cultura política de 1978 en cuestión”, Mediterráneo Económico No. 14 (2008): 144; Paul Ricoeur, Tiempo y narración III. El tiempo narrado (España: Siglo XXI, 1996), 794-795. 
La primera generación de la élite científico-intelectual dominó de 1888 a 1903, en su mayoría fungían como catedráticos y funcionarios del Colegio Nacional Rosales -luego Colegio Civil Rosales- así como editores y directores de periódicos y revistas literarias de circulación regional, aunque también los estudiantes jugaron un papel preponderante. Esta generación creó clubes y sociedades literario-científicas donde establecieron sociabilidades, con posiciones e intereses divergentes, y en cada uno de ellos estos vínculos se asociaban al conjunto de múltiples y contradictorias pertenencias de los actores. Los más conocidos fueron los clubes electorales, donde se ponía de manifiesto un conjunto de recursos organizativos, relacionales e indentitarios para el ejercicio de la soberanía ${ }^{29}$.

Los científicos de la era cańedista fue un grupo de letrados cercanos al poder que compartieron intereses, negocios, amistades, lealtades, compadrazgos, patronazgos, relaciones clientelares y aficiones, con una clara ambición política; además, esos letrados estrecharon relaciones sociales con instituciones científicas y culturales desde donde organizaron veladas literarias y tertulias por cualquier motivo: homenajes, inauguraciones de diferentes recintos, oraciones fúnebres, panegírico, certámenes; convivieron cotidianamente en fiestas y diversiones ${ }^{30}$.

En los inicios del gobierno de Cañedo se crearon diferentes sociedades científico-literarias. En 1877, los profesores del Colegio Rosales, licenciados Gómez Flores, Evaristo Paredes, el doctor Ramón Ponce de León y Ruperto L. Paliza ${ }^{31}$, y los estudiantes José A. Ortiz, Bernardo Vázquez, Mariano Peimbertm, Florentino Arciniega y Ledezma fundaron la Sociedad Río de la Loza y, para 1887 crearon la Asociación Científica Rosales -que difundía nuevos conocimientos de todas las áreas del saber por medio de un periódico- cuyo director fue Sosa y Ávila, quien fue destituido por sus

29 Pilar González Bernardo Quiroz, "La 'sociabilidad' y la historia política”, en Conceptualizando lo que se ve. Francois-Xavier Guerra historiado homenaje, Coods. Erika Pani y Alicia Salmerón (México: Instituto Mora, 2004), 441-448.

30 Jaime Manuel Álvarez Garibay, "Letrados de finales del siglo XIX y principios del siglo XX. Los científicos" (tesis de doctorado en Historia, Universidad Iberoamericana, 2011), 383, 393.

31 Fue director del Colegio Rosales, además estudió en la Escuela Nacional Preparatoria de México y fue discípulo de Gabino Barreda. El Monitor Sinaloense, Culiacán, 27 de mayo de 1900, 2. 
ideas pro-liberales ${ }^{32}$. En 1888, Rafael Cañedo Bátiz (hijo del gobernador), Juan Francisco Vidales y Ramón Ponce de León Jr. formaron la Sociedad Juvenil "Juárez", que estuvo orientada a la creación literaria que se consolidó con el nacimiento del semanario El Progreso. Por último, en 1899, surgió la Sociedad de Ciencias y Letras Gabino Barreda, que fue presidida por el licenciado Ignacio Noris como presidente, Eutimio B. Gómez como vicepresidente, Jesús $M$. Cuén como secretario y Luis Monzón como tesorero $^{33}$.

El Colegio Civil Rosales ${ }^{34}$ fue por excelencia el espacio donde se apostó ese grupo de científicos sinaloenses y desde ahí crearon sociedades científico-literarias, que les sirvió para organizar certámenes, al mismo tiempo realizaron homenajes y oraciones fúnebres a los destacados políticos del cañedismo. Los científicos crearon semanarios y periódicos para difundir conocimientos sobre el positivismo, la ciencia y la política. En esta primera etapa, el grupo científico mostró dispersión, ya que dieron nacimiento a varias agrupaciones, pero una vez que se consolidó el régimen cañedista, en 1898, surgió en el Colegio Civil una asociación moderna: el club Jacobinos. En compaginación con lo nacional, hay que resaltar que el porfiriato fue la época de las asociaciones modernas, el club fue una de ellas, que funcionaba con un club central, concentrando en su sección permanente su red de correspondencia, sus decisiones se imponía a todos ${ }^{35}$. El papel de los clubes era organizar las elecciones de diputados, de gobernadores, de

32 Héctor Carlos Leal Camacho, "El papel de las sociedades político-culturales sinaloenses en la Revolución", Clío No. 27 (2002): 31-32.

33 Marco Antonio Berrelleza Fonseca, De Liceo a Universidad. La institución rosalina: 1872-1922 (Culiacán: Universidad Autónoma de Sinaloa, 1998), 207-209.

34 El Colegio fue un espacio donde confluían intereses comunes como el ocio, la política y las escenas literarias. En 1904 en reconocimiento a la trayectoria del profesor Ruperto L. Paliza, alumnos y maestros organizaron una fiesta y entregaron un fotograbado al festejado. Al evento concurrieron el gobernador Cañedo, el secretario de gobierno Eriberto Zazueta; Ignacio M. Gastélum, Ponce de León, los licenciados Sánchez Velázquez, Evaristo Paredes, Verdugo Fálquez, José Tames, Blas Inguanzo, Ignacio Noris; ingenieros Luis F. Molina, Antonio Moreno; Enrique Peña, profesor Julio G. Arce, Epitacio Osuna, Francisco G. Valenzuela y Quintil Tenorio. El aniversario de la Constitución también fue conmemorado por los alumnos rosalinos, para ello, efectuaron manifestaciones públicas, recorrieron las calles Rosales hasta llegar al quiosco de la plaza Constitución donde el profesor Carlos Cota y el estudiante Carlos Echeverría, representantes del Club Central de Estudiantes Sinaloenses pronunciaron los discursos expresando los ideales liberales y progresistas. El Monitor Sinaloense, Culiacán, 7 de febrero de 1904, 2; 28 de marzo de 1904, 4.

Francois-Xavier Guerra, México, 169. 
presidente de la república; así como de realizar fiestas en honor al onomástico de uno de sus miembros o agasajar un personaje de la política.

El club Jacobinos se constituyó por los siguientes integrantes: los doctores Ruperto L. Paliza (director del Colegio), Ramón Ponce de León, Cipriano Hernández León, licenciados Heriberto Zazueta, Manuel Barrantes, Manuel González Soto, Francisco Verdugo Fálquez e ingenieros Manuel Bonilla, Luis F. Molina ${ }^{36}$, el farmacéutico Antonio H. Moreno, el profesor Carlos Filio y los editores Julio G. Arce, Faustino Díaz y Esteban Flores. Las reuniones se efectuaban en el local del club, en las oficinas del periódico de Díaz, El Monitor Sinaloense, y en La Botica del comercio de los farmacéuticos Moreno y su yerno Arce ${ }^{37}$.

El club Jacobinos funcionó como una asociación de hombres organizados para practicar una actividad común ${ }^{38}$, como la organización de eventos literarios, celebración de onomásticos de sus integrantes y de personajes de la política local y nacional, así como los rituales y festividades cívicas. En 1904, por ejemplo, los jacobinos ofrecieron un concierto vocal e instrumental protagonizado por la compañía artística Herrera Moro, a la cual asistieron los miembros de los clanes familiares ${ }^{39}$, hijas, esposas e hijos de los círculos intelectuales y políticos del régimen cañedista. En ese mismo año, en el onomástico de Eriberto Zazueta hubo orquesta, cena, discursos y felicitaciones ${ }^{40}$.

Los jacobinos sirvieron un banquete al gobernador Cañedo, en el edificio Toma de Agua $^{41}$. El lugar fue adornado con palmas, flores, festones de colores, cortinas de punto y espejos. A cada lado de la puerta se colocaron los retratos de los bustos de Porfirio Díaz y Francisco Cañedo. A la hora de la reunión, Francisco Sánchez Velázquez, Enrique Morten Milley -re-

36 René A. Llanes Gutiérrez y Luis F. Molina, El arquitecto de Culiacán (Culiacán: Colegio de Bachilleres del Estado de Sinaloa y La Crónica de Culiacán, 2002), 122-123.

37 El Monitor Sinaloense, Culiacán, 17 de junio de 1900, 3; 22 de abril de 1900, 2.

38 William Alfredo Chapman Quevedo, "El concepto de sociabilidad como referente del análisis histórico", Investigación y Desarrollo No. 1 (2015): 15-16.

39 El Monitor Sinaloense, Culiacán, 28 de enero de 1904, 2.

40 El Monitor Sinaloense, Culiacán, 17 de marzo de 1904, 3; 12 de marzo de 1905, 2.

41 El Monitor Sinaloense, Culiacán, 7 de abril de 1904, 3. 
presentante de la colonia extranjera- e Ignacio Noris -en nombre de los jacobinos- elogiaron y exaltaron la administración de Díaz y Cañedo ${ }^{42}$. En el aniversario del club, el edificio de los jacobinos se adornaba artísticamente, por ejemplo, en el sexto aniversario, en los portales se colocaron guías de flores, cortinas, espejos y cuadros. El lugar se iluminó con focos incandescentes, lámparas de gasolina y un foco de arco que se instaló en el jardín ${ }^{43}$. Asistieron a la celebración, los clanes familiares cercanos al régimen como los Paredes, Salazar, Retes, Peiro, Zazueta, Bátiz, Almada, Paliza, entre otros ${ }^{44}$.

De 1886 a 1903, la élite intelectual cañedista agrupada alrededor del Colegio Civil y club Jacobinos dominó en la organización de las festividades y rituales cívicos en Sinaloa. Esa primera generación vivió el esplendor de la era cańedista, pues participaron activamente en la reelección de Cañedo como gobernador; fundaron centros artístico-literarios, organizaron y le imprimieron una visión positivista a las festividades cívicas, jerarquizaron los desfiles, bailes y fiestas en clases sociales. Los jacobinos de esa primera generación crearon periódicos afines al régimen cañedista, por ejemplo, Julio G. Arce en 1898 fundó El Mefistófeles ${ }^{45}$, diario de información que permaneció hasta 1908; Faustino Díaz creó en 1892 El Monitor Sinaloense, cuyo director fue Herlindo Elenes Gaxiola, semanario de información que clausuraron los revolucionarios en $1911^{46}$.

Los jacobinos eran ingenieros, periodistas, abogados, arquitectos y químicos. Su centro de ejercicio intelectual fue el Colegio Civil, lugar donde construyeron relaciones de sociabilidad a través de círculos científicos y literarios, tertulias y festividades. Los jacobinos ocuparon un lugar en el gobierno de Cañedo, Eriberto Zazueta fue secretario de gobierno y diputado; Julio G. Arce en 1897 se desempeñó como alcalde suplente y alcalde

42 El Monitor Sinaloense, Culiacán, 10 de abril de 1904, 2.

43 El Monitor Sinaloense, Culiacán, 7 de abril de 1904, 2.

44 El Monitor Sinaloense, Culiacán, 17 de abril de 1904, 2.

45 Su director fue Julio G. Arce y su jefe de redacción Esteban Flores y los colaboradores-redactores eran José Rentería, doctor Enrique González Martínez, Francisco Medina, ingeniero Antonio Moreno, Jesús Andrade, Juan L. Paliza, Carlos Filio y Sixto Osuna.

46 Mabel Valencia Sánchez, "Una mirada sociocultural a la prensa de Sinaloa (1885-1910)”, (tesis de maestría en Historia, Universidad Autónoma de Sinaloa), 11-12. 
primero de Culiacán; Manuel Bonilla formó parte del Supremo Tribunal de Justicia y se desempeñó como regidor del ayuntamiento; en 1900 Faustino Díaz fungió como edil de Culiacán ${ }^{47}$; Rafael Cañedo, Ponce de León, Antonio T. Izábal, Juan B. Rojo, Ignacio M. Gastélum, Felipe Sotomayor, Manuel M. Bátiz y Manuel L. Choza se mantuvieron como diputados en la Legislatura del Estado; y para cerrar, de 1906 a 1910, fungieron como magistrados del Tribunal de Justicia del Estado Francisco Sánchez Velázquez, Ignacio Noris y Luis Urrea Haas.

Esta generación le tocó presidir la era dorada de los rituales cívicos en Sinaloa, para tal fin recolectaban recursos entre empleados de gobierno, comerciantes y obreros, asimismo, organizaban tertulias, obras de teatro y corridas de toros.

\section{VIEJOS Y NUEVOS ACTORES EN LA ORGANIZACIÓN DE LAS FESTIVIDA- DES CÍVICAS}

A partir de 1904 el fervor y los sentimientos patrióticos disminuyeron, sobre ello, la siguiente nota sostiene:

"Nadie, ni se forman juntas particulares, ni se levantan entusiasmos, ni se procura llenar con la iniciativa individual un número siquiera de la celebración de la fiesta. Hemos llegado a pensar que los únicos obligados a trabajar para conmemorar una fecha gloriosa, son las once generosas personas que integran la Junta Patriótica, y si ellas nada hacen, los demás, los particulares, el pueblo, tampoco deben hacer nada. Ni siquiera secundamos con un ligero esfuerzo, los esfuerzos de nuestra Junta Patriótica sino que, por el contrario, parece que nos empeñamos en poner a su actividad cuantos obstáculos están a nuestro alcance, y que todas nuestras tendencias miran a hacer deslucir los actos que las Juntas preparan. Por todas partes levantamos tropiezos; por todas partes

47 Adalberto García Santana, "Las letras sinaloenses en lo ocaso del porfiriato: La Bohemia sinaloense (1897-1899) y arte (1907-1909)", (tesis de maestría en Historia, Universidad Autónoma de Sinaloa, 2010), 102-103. 
hacemos surgir dificultades, y no es raro ver que las personas que abandonan sus negocios para dedicarse a la tarea patriótica [...] con una clase media tan inerme que necesitaría de una poderosa máquina para moverla y darle impulso; con una clase alta indispuesta siempre para el esfuerzo patriótico y dispuesta siempre para la censura $[\ldots] " 48$.

Entre la generación de la etapa dorada del ritual cívico y de la generación de la decadencia, no hay una ruptura, sino continuidad. Lo distintivo de esta nueva etapa, es que hay un contexto histórico-cultural que influyó en la definición de la primera y segunda generación de intelectuales.

El club Jacobino después de 1904 se diluyó, se reactivó nuevamente en 1909, con la elección a gobernador. Los jacobinos optaron por construir otros espacios de sociabilidad, Manuel Bonilla en 1904 fundó la Sociedad de Artesanos de Occidente; Ildefonso D. Velasco y Ponciano Verdugo organizaron la Sociedad de Artesanos "Bernardo Vázquez", integrada por veinte obreros ${ }^{49}$. Carlos Filio creó escuelas de nivel básico, fungiendo como director de la escuela modelo del Distrito, sus auxiliares fueron Nabor Tapia jr., Julián Chávez y señorita Dolores Vega. En esta etapa proliferaron escuelas en Sinaloa, en el distrito de Culiacán para 1907 se contabilizaron cientos de varones como de mujeres ${ }^{50}$. En 1905, Gabriel F. Peláez reactivó el Centro Artístico-literario, se integró con miembros ${ }^{51}$ de la primera y segunda generación.

La primera y la segunda generación compartían el fervor por la organización y, la realización de las festividades patrias. Sin embargo, a principios

48 Anónimo, "Después de las fiestas. Tristes reflexiones", Mefistófeles, Culiacán, 19 de septiembre de 1904, 1.

49 Fungieron Ildefonso D. Velasco como presidente; Francisco Grijalba como vicepresidente, Anastasio Yuriar como prosecretario; y Ponciano Verdugo como tesorero. Mefistófeles, Culiacán, 2 de agosto de 1904, 2.

50 El Monitor Sinaloense, Culiacán, 14 de octubre de 1907, 3.

51 Muchos de ellos eran miembros del club Jacobinos y catedráticos del Colegio Civil Rosales como: Abelardo Medica, Carlos Filio, Francisco Verdugo Fálquez, Francisco Medina, Gabriel F. Peláez, Genaro Estrada, Herlindo Elenes Gaxiola, Ignacio M. Gastélum, Ildefonso D. Velasco, Jesús G. Andrade, Juan L. Paliza, Julio G. Arce, Luis F. Molina, Manuel Bonilla, doctor Ruperto L. Paliza y Samuel Híjar. El Monitor Sinaloense, Culiacán, 2 de febrero de 1905, 2. 
del siglo XX al interior de ambas generaciones se fueron gestando corrientes disidentes políticas que cuestionaron al gobierno cańedista. Por un lado, aparecieron los estudiantes del Colegio Civil, vástagos de familias de antiguos liberales juaristas marginados del poder. En la elección de 1909, donde contendieron para la gubernatura el porfirista Alejandro Redo y el opositor José Ferrel con su epicentro en Mazatlán, el estudiante del Colegio Rafael Buelna, sobrino del liberal juarista Eustaquio Buelna, encabezó un grupo de compañeros en favor de Ferrel y en contra de Redo. Esa actitud le costó ser expulsado del Colegio y como consecuencia fue perseguido por el gobierno local, orillándole a sumarse en 1910 a la Revolución maderista.

La otra vena disidente provino de algunos miembros de la primera generación, el ingeniero Manuel Bonilla ${ }^{52}$, fundador de la Sociedad Mutualista de Occidente (SMO), se convirtió en dirigente de los agremiados ${ }^{53}$ entre los que destacaban obreros, gente con varios oficios y profesionistas. Bonilla optó por la oposición al régimen porfirista, participó en los clubes disidentes del lado de Ferrel, para 1910 junto con el comerciante Amado Zazueta se sumó a los clubes antirreleccionistas y cuando Francisco I. Madero llegó al poder, Bonilla se convirtió en jefe supremo de la Revolución en Sinaloa. Los principios de la SMO se sintetizaban en esfuerzo, honradez, lealtad,

52 Manuel Bonilla nació en 1867 en San Ignacio, Sinaloa. Estudió para ingeniero topógrafo en los Estados Unidos y a su regreso se estableció en Culiacán donde fue regidor del ayuntamiento, director del Periódico Oficial del Gobierno del Estado, miembro supernumerario del Supremo Tribunal de Justicia. Bonilla, en 1904 organizó la fundación de la Sociedad Mutualista de Occidente, de donde fue presidente para el periodo 1907-1908, sus acompañantes en la mesa directiva aparecían: tesorero, Ignacio Bermúdez; Jesús J. García, prosecretario; Francisco Grijalva, contador; vocales, Gumersindo López, Ignacio V. López, Francisco Esceverri, Ramón Moreno; suplentes, Ignacio Herrera y Cairo, José Palazuelos. Al asumir el gobierno provisional de Ciudad Juárez y en reconocimiento a que desde enero de 1910 Bonilla había formado en Mazatlán el club Antirreleccionista de Sinaloa, Madero lo nombró ministro de comunicaciones, cargo que le ratificó Francisco León de la Barra en marzo de 1911. Ya con Madero en el ejecutivo federal, ocupó la misma cartera del 6 de noviembre de 1911 al 27 de noviembre de 1912. Al momento de la decena Trágica, Bonilla ocupó la Secretaría de Fomento. Adalberto García Santana, "Las letras sinaloenses en lo ocaso del porfiriato", 105-106; El Monitor Sinaloense, Culiacán, 17 de septiembre de 1907, 3.

53 Algunos de ellos eran José F. Vega, Martín Ochoa, Francisco A. Sandoval, Prisciliano Flores, Nicolás Aldana, Mauricio Leyva, Manuel Cota, Manuel C. Prieto y Loreto Rodríguez, Ignacio Bermúdez, Jesús J. García, Francisco Grijalva, Gumersindo López, Ignacio V. López, Francisco Esceverri, Ramón Moreno, Ignacio Herrera y Cairo, José Palazuelos y el ingeniero Manuel Bonilla. El Monitor Sinaloense, Culiacán, 17 de septiembre de 1904, 2. 
buena fe, progreso, unión y fraternidad ${ }^{54}$; la organización para cubrir los gastos de sus agremiados - por fallecimiento o enfermedad- realizaba corridas de toros y obras de teatro para allegarse de recursos monetarios ${ }^{55}$. Para educar a sus miembros, la SMO tenía una escuela y una biblioteca "bien organizada, dotada de buenas publicaciones periódicas del país y extranjeras", al mismo tiempo, se impartían conferencias con temas referentes a los diferentes oficios del trabajador y sobre el alcoholismo ${ }^{56}$. Los aniversarios de la Sociedad iniciaban con una obertura de Marina, ejecutada por la orquesta de Florencio Limón, luego se pasaba lista, se instalaba la nueva directiva y se entregaban diplomas a sus socios por su adhesión y honradez y, amor al estudio y al trabajo. En 1907, agremiados distinguidos ${ }^{57}$ recibieron diplomas con letras de oro y artísticas alegorías con la siguiente leyenda: 1904, Cumplimiento, Unidos y Progreso -1907-.

Hay dos elementos que destacar de estas dos corrientes contrarias al régimen cañedista. El primero tiene que ver con la familia Buelna, Rafael y su generación experimentaron en 1900 el desafío que lanzó su tío Eustaquio, quien contendió por la gubernatura contra Cañedo, lo cual provocó que este último mostrara enojo hasta cuando el primero murió en $1907^{58}$. El segundo, se refiere a las sociedades mutualistas encabezadas por Bonilla, quien imprimió a sus agremiados estudio y lectura, además se había educado en la Unión Americana donde seguramente se nutrió de ideas progresistas.

Mazatlán fue la otra ciudad sinaloense -de desarrollo económico y cultural- que se configuró aparte e incluso contra Culiacán, ya que al inicio de su gobierno, Cañedo encontró fuerte oposición en los círculos letrados

54 El Monitor Sinaloense, Culiacán, 18 de octubre de 1907, 3.

55 En 1907, la Sociedad se encargó de cubrir los gastos funerales de Ascensión L. Acosta. El Monitor Sinaloense, Culiacán, 24 septiembre de 1907, 2.

56 El Monitor Sinaloense, Culiacán, 31 de octubre de 1907, 3; 25 de abril de 1907, 3.

57 Recibieron diploma: José F. Vega, Martín Ochoa, Francisco A. Sandoval, Prisciliano Flores, Nicolás Aldana, Mauricio Leyva, Manuel Cota, Manuel C. Prieto y Loreto Rodríguez. El joven Vega recibió además una banda con la siguiente inscripción: Sociedad Mutualista de Occidente -tercer aniversario--Premio a la Constancia y Aplicación.

58 Marco Antonio Berrelleza Fonseca, Culiacán. Crónica de una ciudad, 1878-1912 (Culiacán: Ayuntamiento de Culiacán, 2010), 192-196. 
mazatlecos y comerciantes, y con la consolidación de régimen se disciplinaron, pero siempre estuvo latente la chispa de la disconformidad.

Durante la era cañedista en Mazatlán los actores sociales y políticos construyeron redes de sociabilidad a través de círculos literarios, la prensa, casinos, círculos comerciales, teatros, clubes y sociedades mutualistas. Estos actores participaron en el poder político y disfrutaron del progreso económico porfirista en la región, asimismo, organizaron y promovieron los rituales cívicos, espectáculos y diversiones públicas. Existieron dos generaciones, una -agrupada en clubes integrados por familiares y amigos- que vio nacer el régimen de Díaz-Cañedo que incluso se opuso a ese poder. La segunda generación reorganizó y dio continuidad a esos clubes, pero con intención de discutir sobre temas políticos, literarios, realizar tertulias, bailes y organizar festividades y rituales cívicos. La diferencia con Culiacán, fue que en Mazatlán la primera y segunda generación al ver la oportunidad política -muerte de Cañedo- se organizó y postuló a José Ferrel como candidato a gobernador y, posteriormente se sumaron a la lucha antirreleccionalista encabezada por Madero.

El club Aurora fue una de esas asociaciones decimonónicas, creada por grupos liberales juaristas como José C. Valadés y Antonio Díaz de León, quienes se opusieron al régimen cańedista. Esa situación provocó que Valadés fuera asesinado por órdenes de Cańedo en 1879 y, Díaz de León en 1898 fue procesado y acusado de injuriar al gobernador. La vena disidente no desapareció, el hermano de José, el médico Juan Jacobo, y su primo, el periodista y escritor, José Ferrel reorganizaron en 1895 la Sociedad Literaria club Aurora ${ }^{59}$. Las reuniones se efectuaban en el traspatio de Droguería Central, negocio de la familia Valadés. Las actividades eran discusiones sobre literatura, temas sociales y política, ya que muchos de sus miembros gozaban de poder en el ayuntamiento mazatleco. Los miembros del club

59 Además de la familia Valadés y Ferrel se sumaron -los interesados por la literatura y el liberalismoel ingeniero Manuel Bonilla, el periodista Esteban Flores, el empresario José Berumen, el doctor e intelectual Martiniano Carvajal, el periodista y poeta Amado Nervo, el poeta Ángel Beltrán, Juan Sarabia, Jesús Gómez Flores, Manuel Manzo, Manuel del Río, el director del diario El Correo de la Tarde, Carlos F. Galán y el presbítero Dámaso Sotomayor. Leticia Alvarado Fuentes, "El viejo Mazatlán... donde todo comienza. Identidad, representaciones e historia", (tesis de doctorado en Ciencias Sociales, Universidad Autónoma de Sinaloa, 2010), 160. 
participaron en la organización de las festividades cívicas y de los carnavales. En 1909, los miembros del club con Ferrel a la cabeza configuraron un movimiento político en contra del candidato oficial Alejandro Redo, aunque fueron derrotados electoralmente, sentaron las bases del movimiento maderista en Mazatlán.

Surgieron otras sociedades como el club Amistad, formado por mexicanos e individuos de diferentes procedencias - alemana, francesa, española, belgas y americanos radicados en el puerto- cuyo escudo eran dos manos que se estrechaban y una serpiente erguida en forma de triángulo que las rodeaba, bajo el lema: todos para uno. Mientras que el club Águila Negra nació con el objetivo de especializarse en las actividades de la caza y la pesca, cuyos integrantes fueron los miembros de la élite mazatleca del ámbito político y empresarial, su principal promotor fue Bernardo Vázquez, así como los empresarios Jesús Escovar, Lauro Muro, el dueño de la Fundición de Sinaloa, Alejandro Loubet, Ramón Gómez Peña, Paulino García, Carlos Ramírez y el licenciado Antonio Iriarte. La función del club además de sus fines recreativos organizaba banquetes para sus miembros, por ejemplo, en 1848 festejaron el onomástico de Bernardo Vázquez ${ }^{60}$. En 1861, apareció club Unión o Alemán que celebraba los bailes más fastuosos de la colonia alemana. El club se sumaba a las fiestas cívicas y tradiciones mexicanas, pero también recordaba sus celebraciones y sus triunfos. El 2 de septiembre de 1894, treinta miembros de la colonia alemana celebraron el triunfo de Sedan en la guerra franco-prusiana ${ }^{61}$.

Las sociedades mutualistas mazatlecas también jugaron un papel protagónico en la organización y escenificación de las festividades cívicas. Existía la Sociedad de Artesanos Unidos (que nació en 1875), integrada por obreros textiles, tabaqueros, peluqueros, sastres, zapateros, tipógrafos y trabajadores de las obras del puerto como cargadores, fogoneros, estibadores, carpinteros y albañiles. Sus postulados eran fomentar la instrucción, ilustración y moralidad entre sus socios; estimular a los socios con el buen ejemplo

60 Juan Luis Ríos Treviño, “Sociabilidad y cultura política en Mazatlán, 1877-1909”, (tesis de maestría en Historia, Universidad Autónoma de Sinaloa, 2015), 106-107.

61 Leticia Alvarado Fuentes, “El viejo Mazatlán... donde todo comienza”, 161-164. 
para que cumplan con sus deberes en el trabajo; conciliar el interés de cada empleado con los de la empresa; revisar de común acuerdo los sueldos para dar una retribución justa ${ }^{62}$.

En 1909, las sociedades mutualistas se sumaron a la campaña de Ferrel y al movimiento antirreleccionista encabezado por Francisco I. Madero. Entre las agrupaciones figuraban: Artesanos Unidos que tenía como presidente a Isabel Campa; Mutualista de Zapateros, presidente Javier Maxemín; Ignacio Zaragoza, presidente Juan Ibarra; Juan Escutia, presidente Manuel Manzo; Benito Juárez, presidente Feliz Castillo; y Gremio de Abastecedores, presidente Alejandro Gil ${ }^{63}$.

Un punto importante a destacar es que las raíces del descontento contra el régimen de Cańedo pueden encontrarse en los inicios y durante la consolidación del gobierno. La primera se refiere a las viejas familias liberales juaristas, que como críticos del gobierno de Cañedo fueron acallados, pero posteriormente sus descendientes agrupados en clubes y sociedades mutualistas se volcaron contra los herederos del dictador. La segunda tiene que ver con una nueva generación de comerciantes, profesionistas y obreros que disfrutaron de la bonanza económica porfirista, pero al ver la oportunidad se rebelaron.

\section{EL ESPLENDOR DE LA ESCENIFICACIÓN DEL PODER}

El espectáculo moderno a nivel nacional comenzó el 2 de septiembre de 1883, momento cuando participaron obreros, grupos mutualistas, estudiantes, arzobispado de México, el gobernador de la capital del país, el círculo francés, el club alemán, los americanos, la sociedad italiana, el club inglés y el club Albión. La ciudad festejó dos días de iluminación; las casas del comercio adornaron sus fachadas; hubo procesiones y paseos cívicos, peleas de gallos, bailes y banquetes y, por primera se leyó el acta de independencia. Las funciones de las festividades patrióticas reflejaban la estruc-

62 Benito Ramírez, "El movimiento obrero sinaloense de sus años de formación al inicio de la etapa cardenista”, Clío No. 82 (1992): 81-82.

63 Archivo Histórico de la Universidad Autónoma de Sinaloa (AHUAS), Fondo José Ferrel, "Acta de instalación de clubes”, Mazatlán, 9 de junio de 1909. 
tura social, presentar normas de interacción social en el espacio público y dar cuenta de la relación entre individuos y el gobierno. Asimismo, el ceremonial promovió la idea de un nuevo orden a través de desfiles cívicos y militares, la ceremonia principal, las inauguraciones públicas y las estatuas de los hombres ilustres ${ }^{64}$.

En Culiacán, Sinaloa, los festejos cívicos de los días 15 y 16 de septiembre de 1888 inscritos dentro de la era moderna fueron organizados por la junta patriótica, que diseñó un programa de actividades cívicas ${ }^{65}$. El día 15 inició con salvas, fuegos artificiales, repiques a vuelo de campanas, silbatos de las máquinas de vapor de las fábricas El Coloso, Casa de Moneda, Empresa de Agua y locomotoras de ferrocarril. La plaza de Armas y Rosales, los edificios comerciales, la fachada del palacio de gobierno, la Casa de Moneda, cuarteles del quinto regimiento y, algunas casas particulares fueron adornados con banderas y faroles de múltiples colores. El pabellón nacional se izó en los edificios de gobierno estatal de la federación. En las calles del centro se realizó una procesión integrada por funcionarios, corporaciones, gremios con estandartes, jefes y oficiales del quinto regimiento, alumnos del colegio Rosales y escuelas municipales y, pueblo en general. El punto de llegada fue la plaza Rosales lugar donde el teniente coronel Francisco Ramírez y el doctor Pablo M. Parra pronunciaron la oración cívica, el presidente municipal leyó el acta de independencia y el gobernador Mariano Martínez de Castro terminó vitoreando a los héroes nacionales de 1810 .

Para el 16 de septiembre, se replicó una nueva procesión y pronunciaron un discurso los oradores Ignacio M. Gastélum y el estudiante José María Pastor. El presidente de la Junta Patriótica entregó como obsequio cincuenta pesos a una señora que "era contemporánea de Hidalgo y que se dice haber sido bautizada por aquel gran caudillo" ${ }^{66}$. Desfilaron carros alegóricos, uno conducido por once niñas y otro repartía actas de la independencia. El ritual cerró con una serenata en la plaza de Armas donde asistieron las diferentes clases sociales.

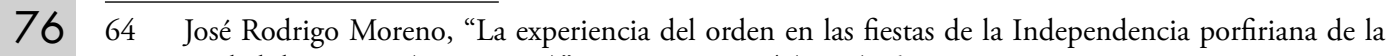
ciudad de México (1887-1900)”, Historia No. 84 (2013): 67.

65 El Correo de Occidente, Culiacán, 20 de septiembre de 1888, 2.

66 El Correo de Occidente, Culiacán, 20 de septiembre de 1888, 3. 
La celebración del día de la independencia tenía dos significados. Primero, el poder porfirista comenzó a utilizar medios espectaculares para señalar su asunción en la historia (conmemoraciones, exponer los valores que exaltaban la manifestación) y afirmar su energía (ejecuciones) ${ }^{67}$. Segundo, mostrar los logros de la modernidad, como el ferrocarril, la industria, la paz, el orden $^{68}$, la educación y, las clases sociales que se definieron en los teatros y los rituales cívicos. Esta tesis se confirma, en 1891 cuando en la ciudad de México como en Culiacán las multitudes inundaron las calles y las plazas ${ }^{69}$. En la capital sinaloense el 15 y 16 de septiembre fue el pretexto para hacer coincidir el fervor patriótico con la inauguración de la escuela Miguel Hidalgo. En lo que respecta al ritual cívico, las autoridades, los empleados y los alumnos del colegio Rosales realizaron una procesión que partió del palacio de gobierno y terminó en la plaza Rosales, lugar donde vitorearon a los héroes de la patria y la banda del Estado tocó la obertura Anáhuac en honor a la nación ${ }^{70}$. El 16, hubo cabalgata, se leyó el acta de independencia y en la plaza de Armas se ofreció un baile a los artesanos de la ciudad; mientras que la élite celebraba en los casinos y en los teatros.

La configuración regional de Culiacán y Mazatlán históricamente evolucionaron de manera diferenciada. La élite mazatleca siempre rivalizó cultural, política y económicamente con el grupo de poder de Culiacán. Los rituales cívicos no fueron la excepción, el 15 de septiembre de 1891, la Junta Patriótica, autoridades civiles y militares, ayuntamiento, cuerpo consular, representantes de las naciones extranjeras y alumnos de escuelas municipales y particulares, realizaron una procesión que partió de Olas Altas y terminó en la plaza Hidalgo, lugar donde cien niñas entonaron el himno nacional y el prefecto de distrito leyó el acta de independencia ${ }^{71}$. Más tarde

67 Georges Balandier, "El poder en escenas, 24.

68 Jesús Jiménez Castillo, "El discurso político de la modernización. Un estudio de las ideas políticas en el porfiriato y su repercusión en el Estado de Veracruz" (tesis de doctorado en Historia y Estudios Regionales, Universidad Veracruzana, 2007), 384.

69 El espacio se adornaba pomposamente, en la esquina del Portal de Mercaderes fue instalado un arco de musgos y de flores, y en las pilastras se colocaron grandes cuadros de rosas blancas y rojas, la parte superior estaba tapizada de flores. En la mayoría de los balcones se colocaron cortinas y banderas, y los edificios particulares estaban adornados y la fachada de la Concordia y la zapatería de la Profesa fueron cubiertas de flores. El Monitor Republicano, México, 16 de septiembre de 1891, 3.

70 El Correo de la Tarde, Mazatlán, 21 de septiembre de 1891, 1.

71 El Correo de la Tarde, Mazatlán, 14 de septiembre de 1891, 1 y 2. 
se celebró un concierto en el teatro Rubio, luego se organizó una procesión encabezada por dos niñas con trompetas, seguidas por los carros de los clubes Benito Juárez (dedicado a la música), Águila Negra ${ }^{72}$, Amistad $^{73}$, y Unión o Alemán ${ }^{74}$; y en un último lugar avanzaban la comitiva oficial, el cuerpo consular, la Junta Patriótica y el presidente del ayuntamiento ${ }^{75}$.

El espectáculo cívico mazatleco hace imaginar las procesiones del Estado-teatro en el Bali, que se integraban en primer lugar por el cuerpo de lanceros intercalados con música, seguidamente de un gran número de hombres y mujeres llevando ofrendas, finalmente un caballo del difunto alegremente engualdrapado. A estos los seguía el joven rey con un gran séquito de príncipes y nobles. Tras de ellos, venía el pandita o sumo sacerdote, llevado en una silla abierta, alrededor de la cual se envolvía uno de sus extremos de un rollo de ropa que quería representar una enorme serpiente ${ }^{76}$.

En Mazatlán, las procesiones cívicas simbolizaban una verdadera religión de la patria. El 16 de septiembre, por ejemplo se construyeron cinco altares, el primero se instaló en el club Benito Juárez dedicado a los héroes nacionales, el segundo en el club Aurora, el tercero en la Sociedad Mutualista alusivo a Hidalgo, el cuarto en el club Amistad referido a la patria y, el último se estableció en la plaza Hidalgo, lugar donde se leyó el acta y

72 Decorado con una Minerva rodeada de los atributos de la ciencia y, Diana Cazadora que habiendo sorprendido un venado en un bosque, lo tenía sentenciado a muerte y parecía disponerse a ejecutar la sentencia dejando escapar del arco puesta en combate la flecha voladora. Y no muy lejos, un jovencito recogía sus redes como satisfecho de la pesca. El Correo de la Tarde, Mazatlán, 17 de septiembre de $1891,2$.

73 Adornado por seis columnas doradas, unidas por una cadena de flores artificiales, bajo un dosel se colocaba el escudo de la sociedad, que eran dos manos que se estrechaban, rodeaba el escudo una serpiente, símbolo de la unión universal y al final un lema rezaba: Todos para Uno. A los costados del dosel estaban colocadas las banderas mexicana, española y alemana, belga, francesa y americana; al pie del dosel se situaban dos ángeles que representaban la Fama y la Gloria; estos ángeles eran Victoria Tapia y Virginia Goosties. El carro fue adornado por las señoritas Elodia Tapia, Ermila López y Rosa González.

74 Adornado artísticamente y con una bandera, que enorgullecía a los miembros de la colonia alemana, al mismo tiempo entonaban el himno alemán.

75 El Correo de la Tarde, Mazatlán, 18 de septiembre de 1891, 1.

76 Clifford Geertz, Negara. El Estado-teatro en el Bali del siglo XIX (Barcelona: Paidós, 2000), 178179. 
el vicepresidente interino Miguel Gaxiola dio el grito de independencia ${ }^{77}$. Este espectáculo público era puesto en escena por la élite mazatleca, quienes interaccionaban entre ellos, ya sea en brindis, en el teatro Rubio, en el Casino o en las procesiones. Mientras que la clase obrera se replegaba a la plaza Machado y en el edificio de Sociedad Mutualista de Zapatería, lugar donde se les ofrecía comida y un baile.

De 1888 a 1903, la teatralización del poder se manifestó a través de fastuosas decoraciones e iluminaciones de las fachadas de los edificios públicos, de las casas particulares y de las plazas públicas. Aunado, a las procesiones, desfile de carros alegóricos, serenatas, bailes, altares a los héroes, oraciones cívicas y concentraciones multitudinarias. Esto se relaciona con la inserción de Díaz como parte del ceremonial de la patria y el culto a la figura presidencial. Díaz es concebido como el padre de la gran familia mexicana, juez y héroe nacional equiparable a Juárez, Cuauhtémoc e Ignacio Zaragoza. Las ascensión de Díaz al panteón heroico corresponde al reconocimiento de sus méritos en la lid y como "adalid de la paz" y la incorporación de México al concierto mundial de las naciones civilizadas ${ }^{78}$.

\section{ENTRE LA DECADENCIA Y REVITALIZACIÓN DEL RITUAL CÍVICO}

A partir de 1904, el contexto social y cultural sinaloense se modificó. Apareció el cinematógrafo, la matinée musical y literaria, y en Mazatlán se modernizó el carnaval. El ritual cívico también se transformó, el 15 y 16 de septiembre fue un pretexto para el ocio y la diversión. Además el fervor patriótico se relajó, pues la festividad cívica en Culiacán se redujo a una velada musical y literaria en el teatro Apolo ${ }^{79}$, que abrió con una pieza de oratoria, para después seguir con recitaciones de poemas musicales, popurrí de ópera y, por último la velada cerró con la oración cívica y la entonación del himno nacional ${ }^{80}$. Esta actividad estaba reservada para la élite de

77 El Correo de la Tarde, Mazatlán, 17 de septiembre de 1891, 2.

78 Arnaldo Moya Gutiérrez, "Los festejos cívicos septembrinos, 66.

79 El lugar fue decorado con festones, banderas, escudos y cortinajes. El foro se ostentaba, bajo artísticos doseles, un buen retrato del cura de Dolores; a los lados del cuadro se colocaron dos grandes estatuas, y completaban la ornamentación, pabellones de armas, cortinajes y banderolas de armas, dispuestos convencionalmente. Mefistófeles, Culiacán, septiembre 14 de 1904, 1.

Mefistófeles, Culiacán, 17 de septiembre de 1904, 1. 
Culiacán ${ }^{81}$ entre los que destacaban miembros del círculo oligárquico ${ }^{82}$ y notables que pertenecían a los profesionistas con prestigio social y económico $^{83}$.

Los rituales cívicos como parte de la religión de la patria dejaron de tener mayor importancia, al grado de ser sustituidos por la celebración de la reelección y onomástico del gobernador Francisco Cañedo, que se efectuaba el 27 de septiembre y 5 de octubre respectivamente. Para tal efecto se organizó un comité y los culiacanenses adornaron las fachadas de sus casas, las calles y la plaza Rosales fue iluminada; las campanas repiquetearon, sonaron los silbatos de la fábrica El Coloso; la élite industrial y política así como las sociedades mutualistas felicitaron al gobernador, por último desfilaron ochenta carros alegóricos y, la festividad cerró con los combates de flores y confeti ${ }^{84}$.

Para el 15 de septiembre de 1905, solamente la Sociedad Mutualista de Occidente desfiló por las calles de Culiacán, y finalizó en el palacio de gobierno, lugar donde el secretario de gobierno Eriberto Zazueta emuló a Hidalgo y, el secretario del ayuntamiento Manuel Hernández leyó el acta de independencia y se entonó el himno nacional. Al final hubo una fiesta en el local Los Canarios. El 16, solo desfilaron los guardias municipales rurales y, para culminar Enrique O'Farril emitió un discurso y Digna Torres recitó una poesía. La celebración del día de la independencia definió las clases sociales: por un lado, la Sociedad de Artesanos "Bernardo Vázquez", la Sociedad Mutualista de Obreros y la Iglesia metodista disfrutaron de un baile ${ }^{85}$ por otro, la élite cañedista se volcó al teatro Apolo $^{86}$ para degustar la matinée artística y literaria ${ }^{87}$.

81 Las plateas y los proscenios eran para los notables de Culiacán. Los sectores medios y las agrupaciones obreras se instalaban en las demás localidades. Mefistófeles, Culiacán, 11 de septiembre de 1904, 2.

82 Apellidos más representativos eran Almada, Andrade, Batiz, Blancarte, Díez Martínez, Esqueda, Martínez de Castro, Ramos, Redo, Rojo, Uriarte, Urrea y Vega.

83 Víctor Hugo Aguilar Gaxiola, Las familias poderosas del Cabildo de Culiacán, 1872-1910 (Culiacán: Universidad Autónoma de Sinaloa y H. Ayuntamiento de Culiacán, 2004), 98-99.

84 Mefistófeles, Culiacán, 28 de septiembre de 1904, 3; 29 de septiembre de 1904, 2.

8085 Mefistófeles, Culiacán, 18 de septiembre de 1905, 2.

86 Fue adornado con cortinajes, festones, flores y banderolas, se colocaron grandes escudos en la primera serie de palcos con nombres de los héroes.

87 Mefistófeles, Culiacán, 18 de septiembre de 1905, 2. 
De 1904 a 1904, la principal protagonista de la organización del ritual cívico estuvo presidida por la Sociedad Mutualista de Occidente, encabezada por Manuel Bonilla. Esa agrupación realizó un baile en el patio del ayuntamiento $\mathrm{y}$, algunos de sus miembros hicieron declamaciones, al tiempo que lanzaron discursos exhortando a sus socios a luchar por el progreso.

La celebración del día de la independencia se revitalizó a partir de 1907, ya que se acercaba el Centenario de la Independencia. Para ello, a nivel nacional se creó la Comisión Nacional del Centenario de la Independencia (CNCI), y en Sinaloa surgió la Junta Central del Centenario. Para ese entonces, en Culiacán, la plaza de Armas fue iluminada con incandescentes focos y adornada con guías florales, banderas y farolillos. El quiosco se decoró con cortinas, lienzos y banderines multicolores ${ }^{88}$. El escenario fue inaugurado por una banda musical que atrajo una inmensa multitud. El 15 de septiembre, la escuela industrial, la Junta Patriótica, la Sociedad Mutualista, los empleados públicos y pueblo en general desfilaron hasta llegar al palacio de gobierno, punto donde el secretario del ayuntamiento Manuel Hernández León leyó el acta de independencia, el licenciado Zazueta levantó la bandera vitoreando a la patria y los héroes de la independencia. Al final se cantó el himno nacional y se ofrecieron cerveza y sandwiches.

El 16, hubo salvas, repiques, música y en el teatro Apolo ${ }^{89}$, se organizó la matinée musical y literaria. La élite y la comitiva oficial disfrutaron de un programa ${ }^{90}$ que inició con el himno nacional, para seguir con la canción Las Alegres Comadres de Windsor. Luego, Bernardo Gastélum vociferó la oración cívica, y el delegado de la CNCI instaló la Junta Central de las

88 El Monitor Sinaloense, Culiacán, 17 de septiembre de 1907, 2.

89 En el foro se ubicaba un gran trofeo formado con fusiles, banderas, metrallas, cornetas, tambores, mochilas y cascos. En la parte superior del trofeo, estaba el dosel del cortinaje rojo y oro, que abrigaba el retrato de Miguel Hidalgo. El plafón del teatro estaba cubierto por su gran sombrilla de festones con minúsculas banderas. Los antepechos de los palcos ostentaban lienzos azules, rojos y tricolores, soles dorados, con los nombres de los héroes, águilas, festones multicolores con polvo de oro y guías florales.

90 Entre las actividades artísticas más importantes estaban la fantasía Magdalena ejecutada por Florencio Limón; la niña Concepción Ramírez recitó la poesía a Hidalgo escrita por Tablada; la Banda del Estado deleitó a la concurrencia con El Beso, vals de Siracusa; la orquesta integrada por Ángel Viderique, Manuel Larios, Alberto Paredes, Alfredo Calderón, Juan Solano, Alfredo Calderón, Juan Solano Jr., Arturo Calderón y el niño Pascual Viderique deleitaron la obertura Cavallería. 
Fiestas del Centenario de Sinaloa ${ }^{91}$. El espectáculo se desgranó en desfiles, oraciones cívicas, música de banda en la plaza Constitución.

El punto de inflexión fue 1907, porque la Sociedad Mutualista y la Junta del Centenario reactivaron la celebración del día de la independencia. La Junta Patriótica realzó el día de la patria entregando tres premios ${ }^{92}$ a las casas mejores adornadas de la calle Miguel Hidalgo.

El Centenario de la Independencia en 1910, fue celebrado ostentosa y fastuosamente en las ciudades y los poblados de Sinaloa. En Villa Unión, distrito de Mazatlán, las plazas, los edificios públicos y las casas particulares fueron adornados. Los pobladores crearon un parque que bautizaron con el nombre de Hidalgo; en la plaza Bernardo Vázquez -adornada con palapas, banderolas y festones, globos y focos incandescentes- se llevó a cabo un baile $^{93}$. Se leyó el acta de independencia, se vociferaron oraciones cívicas y se desarrollaron desfiles de carros alegóricos ${ }^{94}$. En los pueblos de Siqueros y Copala, se agregó la corrida de toros y quema de castillos, así como la reparación de la plaza Juárez y de la banqueta de la calle Independencia ${ }^{95}$.

El Centenario representó el triunfo del republicanismo liberal y la culminación del proyecto liberal de construcción nacional. Proyecto fructífero bajo la administración de la figura patriarcal de Díaz, quien fue el centro

91 Cuyos integrantes fueron Manuel Clouthier, doctores Ruperto L. Paliza y Ramón Ponce de León, Severiano Tamayo, Tomás Salmón, licenciado Ignacio M. Gastélum, Faustino Díaz, José Crisóforo Avedaño y José María Cabanilla. El propósito de la comisión era organizar los festejos del primer centenario del grito de dolores en todos los pueblos de Sinaloa. El Monitor Sinaloense, Culiacán, 17 de septiembre de 1907, 3 .

92 Los tres primeros recibieron quince, diez y cinco pesos, en moneda de oro, que se adhirieron a tarjetas con artísticas alegorías conmemorativas pintadas en acuarela por el señor Ildefonso D. Velasco. Las tarjetas llevaban como inscripción "premio A, recompensa de la Junta Patriótica de Culiacán por el adorno de la calle Miguel Hidalgo en el $97^{\circ}$ aniversario de la Independencia".

93 El Correo de la Tarde, Mazatlán, 20 de septiembre de 1910, 1.

94 La Patria fue ocupado por la seńorita Elisa González y sus acompañantes los niños Jesús Tostados y Roberto Ramírez; La Industria portaba telares, máquinas, operarios y, máquinas en movimiento simulando trabajar; y La Agricultura se registró a última hora. Por la noche, no faltó la serenata y el baile, que fue aprovechado por las notables señoritas del lugar, para vender refrescos, cerveza helada, nieve y flores, con el fin de aportar recursos para la construcción de la iglesia.

95 El Correo de la Tarde, Mazatlán, 21 de septiembre de 1910, 1. 
del escenario de las fiestas de Centenario, ya que compartía el altar de la patria como el artífice de la paz y el progreso alcanzado por el país. Esos avances mostrados fueron las calles pavimentadas, bulevares, parques con grandes jardines y los servicios públicos como drenaje, electricidad, gas y teléfono; así como hospitales, escuelas y cárceles ${ }^{96}$.

\section{CONCLUSIÓN}

Después del análisis de las dos generaciones de intelectuales y de los rituales cívicos se llegó a dos resultados. El primero tiene que ver con las raíces de la disidencia política y revolucionaria de 1910 en Sinaloa. Esa vena se configuró al interior de las dos generaciones, en Culiacán por ejemplo, la familia Buelna de corte liberal juarista siempre se opuso al gobierno de Cañedo, pero su principal representante Eustaquio Buelna fue derrotado en la contienda electoral en 1900 y murió en 1907 odiado por el dictador. No terminó ahí la oposición, su sobrino Rafael Buelna y otros estudiantes del colegio Rosales al morir Cañedo y al saber de la candidatura del opositor José Ferrel, se sumaron a su campaña y, luego terminaron en las filas maderistas. La otra línea de disidencia provino de las sociedades mutualistas encabezadas por Manuel Bonilla, quien impulsó el estudio, la lectura y la cooperación dentro de las agrupaciones obreras, pero además sus integrantes se politizaron, pues había al interior de esa agrupación abogados, ingenieros, periodistas y profesores.

En cuanto a Mazatlán, históricamente se configuró en oposición a Culiacán; desde la década de 1830, la élite mazatleca integrada por comerciantes extranjeros se enfrentaron abiertamente contra el grupo de la Vega que controlaba la capital sinaloense. Una vez que Francisco Cańedo arribó al poder, los clanes liberales juaristas como los Valadés, los Rete y los Avedaño se volvieron los principales críticos del gobernador. A estos opositores también se sumaron los comerciantes, poetas y periodistas, pero una vez que se

96 María de las Nieves Rodríguez y Méndez de Lozada, "La Celebración del Centenario de la Independencia de México en 1910 a través de algunos grabados de José Guadalupe Posadas", Takwá No. 11-12 (2017): 162; María Eugenia Ponce Alcocer, "La conmemoración de 1910, la celebración del progreso", en Los Centenarios de la independencia. Representación de la historia patria entre la continuidad y el cambio, eds. Stephan Scheuzger y Sven Schuster (Eichstätt, 2013), 38, 43, 28-29. 
consolidó el régimen cañedista, nos tuvieron otra opción que disciplinarse, sin embargo, el descontento quedó latente; aunque algunas voces como la de los periodistas José Ferrel y Heriberto Frías, así como la de los editores Andrés Avedaño y Francisco Valadés a través del periódico El Correo de la Tarde, no cesaban en sus críticas contra la política cañedista. Finalmente, en 1909, después de la muerte del patriarca, los comerciantes agrupados alrededor del Círculo Comercial Benito Juárez, los clubes y las sociedades mutualistas perfilaron la candidatura de José Ferrel, quien se lanzó a la campaña contra el heredero de Cañedo, Diego Redo.

Un segundo resultado, alude a los rituales cívicos que dibujaban claramente el proyecto de la modernidad porfirista. El espectáculo mostraba el progreso a través del ferrocarril, las fábricas, la ciudad -con sus calles y avenidas trazadas por el ingeniero Molina, así como las plazuelas y sus respectivos quioscos y jardines- y las escuelas. Mientras que el orden era representado por medio de los desfiles, caminatas, procesiones, discursos, lectura del acta de independencia. Además, esas festividades marcaban muy nítidamente las clases sociales, por un lado, los obreros realizaban sus bailes en las plazas, calles y patios del ayuntamiento; por otra parte, las élites disfrutaban de bailes, tertulias y matinée musical en casinos, teatros y domicilios privados.

\section{Bibliografía}

\section{Fuentes primarias}

Archivo Histórico del Ayuntamiento de Mazatlán (AHAM).

Archivo Histórico de la Universidad Autónoma de Sinaloa (AHUAS).

\section{Hemerografía}

El Correo de la Tarde, Mazatlán, 1891-1904, 1910.

El Correo de Occidente, Culiacán, 1888.

Mefistófeles, Culiacán, 1904-1906.

84 El Monitor Sinaloense, Culiacán, 1900-1907.

El Monitor Republicano, México, 1891. 


\section{Fuentes secundarias}

Anónimo. "Después de las fiestas. Tristes reflexiones". Mefistófeles, Culiacán, septiembre 19 de 1904.

Alvarado Fuentes, Leticia. "El viejo Mazatlán... donde todo comienza. Identidad, representaciones e historia". (Tesis de doctorado en Ciencias Sociales, Universidad Autónoma de Sinaloa, 2010).

Ángel Palou, Pedro. "Intelectuales y poder en México". América Latina Hoy No. 47 (2007): 78-80.

Alan, Knight. La Revolución mexicana. Del porfiriato al nuevo régimen constitucional. México: Fondo de Cultura Económica, 2010.

Annino, Antonio y Francois-Xavier Guerra (Coods.). Inventando la nación. Iberoamérica. Siglo XIX. México: Fondo de Cultura Económica, 2003.

Alzaga Sánchez, Oscar. "Del bicentenario de la Independencia, el centenario de la Revolución y la historia”. Alegatos No. 75 (2010): 629-638.

Balandier, Georges. El poder en escenas. De la representación del poder al poder de la representación. Barcelona: Ediciones Paidós, 1994.

Berrelleza Fonseca, Marco Antonio. De Liceo a Universidad. La institución rosalina: 1872-1922. Culiacán: Universidad Autónoma de Sinaloa, 1998.

Bustos Lozano, Guillermo. "Del primer centenario de la independencia ecuatoriana: los sentidos divergentes de la memoria nacional”. Historia Mexicana Vol. LX, No. 1 (2010): 473-524.

Brezzo, Liliana M. "Reparar la nación’ discursos históricos y responsabilidades nacionalistas en Paraguay". Historia Mexicana Vol. LX, No. 1 (2010): 197-242.

Brenes Tencio, Guillermo. "Héroes y liturgias del poder: la ceremonia de la apoteosis". Revista de Ciencias Sociales Vol. IV, No. 106 (2004): 107-121.

Beezley, William H. La identidad nacional mexicana: la memoria, la insinuación y la cultura popular en el siglo XIX. México: El Colegio de la Frontera, El Colegio de San Luis y El Colegio de Michoacán, 2008.

Campos Pérez, Lara. "La república personificada. La fiesta porfiriana del 2 de abril (1900-1911)”. Estudios de Historia Moderna y Contemporánea de México No. 51 (2016): 53-71. 
Correa Ramírez, John Jaime. "El discurso del civismo en Pereira o la 'sacralidad' de lo público durante el siglo XX”. Historielo No. 2 (2009): 7-31.

Cid, Gabriel. "Ritos para una nueva legitimidad: ceremoniales constitucionales y republicanismo en Chile (1812-1833)". Historia Crítica No. 47 (2012): 17-43.

Chapman Quevedo, William Alfredo. "El concepto de sociabilidad como referente del análisis histórico". Investigación y Desarrollo Vol. 23, No. 1 (2015): 1-37.

Dávila, Luis Ricardo. "Centenario e inventario de los problemas venezolanos”. Historia Mexicana Vol. LX, No. 1 (2010): 243-299.

Escovar Wilson-White, Alberto. "Bogotá en tiempos de la celebración del primer centenario de la independencia”. Historia Mexicana Vol. LX, No. 1 (2010): 525-559.

Fernández Poncela, Ana M. "Conmemoraciones, lugares de la memoria y turismo: Querétaro”. Alegatos No. 73 (2009): 532-554.

Florescano, Enrique. "Patria y nación en la época de Porfirio Díaz". Signos Históricos No. 13 (2005): 152-157.

García Santana, Adalberto. "Las letras sinaloenses en lo ocaso del porfiriato: La Bohemia sinaloense (1897-1899) y arte (1907-1909)”. (Tesis de maestría en Historia, Universidad Autónoma de Sinaloa, 2010).

Guerra, Francois-Xavier. México: del Antiguo Régimen a la Revolución.

México: Fondo de Cultura Económica, 1988.

Geertz, Clifford. Negara. El Estado-teatro en el Bali del siglo XIX. Barcelona: Paidós, 2000.

González-Reyes, Gerardo. "Celebrar y festejar, que la nación se va a inventar. Breve arqueología de la construcción del calendario y la memoria cívica en México y sus expresiones populares". Contribuciones desde Coatepec No. 25 (2013): 41-66.

González, Luis. Pueblo en Vilo. Zamora: El Colegio de Michoacán, 1995. González Bernardo Quiroz, Pilar. "La 'sociabilidad' y la historia política”. En Conceptualizando lo que se ve. Francois-Xavier Guerra historiado homenaje, coordinado por Erika Pani y Alicia Salmerón. México: Instituto Mora, 2004, 441-448.

Jorquera Núñez, Cinthia Guadalupe. "La transformación de la vida cotidiana en Culiacán durante la época del cañedismo (1877-1909)”. 
(Tesis de licenciatura..., Universidad Autónoma de Sinaloa, 2017). Jiménez Castillo, Jesús. "El discurso político de la modernización. Un estudio de las ideas políticas en el porfiriato y su repercusión en el Estado de Veracruz". (Tesis de doctorado en Historia y Estudios Regionales, Universidad Veracruzana, 2007).

Koselleck, Reinhar. Los estratos del tiempo: estudios sobre historia. Barcelona: Ediciones Paidós, 2001.

Leal Camacho, Héctor Carlos. "El papel de las sociedades político-culturales sinaloenses en la Revolución”. Clío No. 27 (2002): 27-52.

Lempériere, Annick. "Los dos centenarios de la independencia mexicana (1910-1921): de la historia patria a la antropología cultural”. Historia Mexicana Vol. 45, No. 2 (1995): 327-328.

Leach, E. R. Sistemas políticos de la alta Birmania. Estudios sobre la estructura social Kachin. Barcelona: Editorial Anagrama, 1975.

López Gallegos, Alejandra y Aquiles Amparán. "Símbolos, lenguaje y espectáculos en la democracia: el escepticismo político de Murray Edelman”. Espiral No. 50 (2011): 101-139.

Llanes Gutiérrez, René A. y Luis F. Molina. El arquitecto de Culiacán. Culiacán: Colegio de Bachilleres del Estado de Sinaloa y La Crónica de Culiacán, 2002.

Marías, Julián. El método histórico de las generaciones. Madrid: Revista de Occidente, 1949.

Marques del Castillo, Daniela. "La fiesta del Cinco de Mayo en San Luis Potosí, 1862-1867”. (Tesis de licenciatura en historia, Universidad Autónoma de San Luis Potosí, 2009).

Malosetti Costa, Laura. "Arte e historia en los festejos del centenario de la revolución de mayo en Buenos Aires". Historia mexicana, Vol. LX, No. 1 (2010): 439-470.

Marta Mailhe, Alejandra. "Discursos e independencia en América Latina: reflexiones críticas”. Revista de Filosofía y Teoría Política No. 41 (2010): 157-175.

Moya Gutiérrez, Arnaldo. "Los festejos cívicos septembrinos durante el porfiriato, 1877-1910". En Modernidad, tradición y alteridad, la ciudad de México en el cambio del siglo (XIX-XX), editado por Claudia Agostini y Elisa Epeckman. México: Instituto de Investigaciones Históricas-UNAM, 2001. 
Ortega Noriega, Sergio. Breve historia de Sinaloa. México: El Colegio de México y Fondo de Cultura Económica, 1999.

Pérez Montfort, Ricardo. "El pueblo y la cultura. Del porfiriato a la revolución". En La identidad nacional mexicana como problema político y cultural. Nuevas miradas, coordinado por Raúl Béjar y Héctor Rosales. Cuernavaca: Universidad Nacional Autónoma de México, 2005, 60-61.

Pereyra Chávez, Nelson E. "Historia, Memoria, identidad y performance en una fiesta: la Semana Santa de Ayacucho”. Dialogía Vol. 4 (2009): 222-263.

Ramírez, Benito. "El movimiento obrero sinaloense de sus años de formación al inicio de la etapa cardenista". Clío No. 82 (1992): 80-85.

Rabotnikof, Nora. "El Bicentenario en México: la historia desde la política". Revista de sociología No. 24 (2010): 221-242.

Rajchenber, Enrique y Aleida García Aguirre. "Memoria e historia en los cumpleaños de la Patria”. Bajo el Volcán Vol. 10, No. 16 (2011): $17-36$.

Rodrigo Moreno, José. "La experiencia del orden en las fiestas de la Independencia porfiriana de la ciudad de México (1887-1900)". Historia No. 84 (2013): 59-88.

Rodríguez Ávila, Sandra Patricia. "Construcción de la memoria oficial en el Centenario de la Independencia: el Compendio de Historia de Colombia de Henao y Arrubla”. Folio No. 32 (2010): 23-42.

Rodríguez, María de las Nieves y Méndez de Lozada. "La Celebración del Centenario de la Independencia de México en 1910 a través de algunos grabados de José Guadalupe Posadas". Takwá No. 11-12 (2017): 157-172.

Roldán, Diego P. "Imágenes, juegos, rituales y espacios. Las interacciones socioculturales entre la elite y sectores populares durante las entreguerras. La incultura en Rosario (Argentina)". Historia No. 28 (2009): 683-714.

Ricoeur, Paul. Tiempo y narración III. El tiempo narrado. España: Siglo XXI, 1996.

88 Ríos Trevińo, Juan Luis. "Sociabilidad y cultura política en Mazatlán, 1877-1909”. (Tesis de maestría en Historia, Universidad Autónoma de Sinaloa, 2015), 106-107. 
Sáez-Arance, Antonio. "Entre la autocomplacencia y la crisis: discursos de chilenidad en el Primer Centenario". Historia Mexicana Vol. LX, No. 1 (2010): 369-396.

Sánchez-Prieto, Juan María. "Historia y generaciones: la cultura política de 1978 en cuestión”. Mediterráneo Económico No. 14 (2008): 143167.

Serrano Álvarez, Pablo. Porfirio Díaz y el porfiriato. Cronología (18301915). México: Instituto Nacional de Estudios Históricos de la Revolución Mexicana, 2012.

Vargas Álvarez, Sebastián. "Monumento Estela de Luz: disputa en torno a los usos públicos de la historia en el México del Bi/Centenario". Tempo e Argumento No. 19 (2016): 130-161.

Valencia Sánchez, Mabel. "Una mirada sociocultural a la prensa de Sinaloa (1885-1910)”. (Tesis de maestría en historia, Universidad Autónoma de Sinaloa, 2007).

Zárate Toscano, Verónica. "Los hitos de la memoria o los monumentos en el centenario de la independencia de México. Ópera imaginaria en una obertura”. Historia mexicana Vol. LX, No. 1 (2010): 85-135.

Para citar este artículo: Santos Cenobio, Rafael. "Actores y ritual cívico durante el porfiriato: la celebración del día de la independencia en Sinaloa, México, 1888-1910”, Historia Caribe Vol. XIV No. 34 (Enero-Junio 2019): 55-89. DOI: http://dx.doi.org/10.15648/hc.34.2019.2 